\title{
Comment: The effect of post-conflict transition on deforestation in protected areas in Colombia
}

\author{
Daniel Schoenig ${ }^{1, *}$, Jérôme Dupras ${ }^{2}$, and Christian Messier ${ }^{1,2}$ \\ ${ }^{1}$ Département des Sciences Biologiques, Université du Québec à Montréal, Montréal, QC, Canada \\ ${ }^{2}$ Département des Sciences Naturelles, Institut des Sciences de la Forêt Tempérée, Université du Québec en \\ Outaouais, Ripon, QC, Canada \\ *daniel.schoenig@protonmail.com
}

\begin{abstract}
A recent study on Colombian protected areas has found an increase in deforestation after ending armed conflict. The authors propose several drivers behind this trend and take their findings as proof of how these drivers specifically affect protected areas and render them particularly vulnerable to deforestation during post-conflict transition. However, after conducting an extended analysis of the data, we show that the original study merely noticed a national trend of increased deforestation in Colombia, and that forests in national protected areas are actually less affected by the transition than other forests in Colombia. Given these results, the proposed drivers and conservation lessons of the original study can only be regarded as speculative. In this comment, we point out the conceptual and statistical shortcomings of the original study to discuss how to improve forest change analyses regarding policy relevance.
\end{abstract}

\section{Introduction}

In their study ${ }^{1}$ on Colombian national protected areas, Clerici et al. investigated how deforestation is influenced by armed conflict. The authors evaluated the change in forest loss in and around 39 protected areas before and after a peace agreement was reached to end military conflict between the Colombian government and the guerrilla groups of the Fuerzas Armadas Revolucionarias de Colombia (FARC). The authors present their observations regarding increase in forest loss, then propose several drivers that are related specifically to protected areas, and finally argue that these drivers are responsible for forest loss observed in protected areas.

After replicating the original study ${ }^{1}$ and conducting an extended statistical analysis, we found that the interpretations of the authors are not supported by their data. The analysis and conclusions presented in the study ${ }^{1}$ appear to be affected by four key conceptual and statistical shortcomings: (1) no reference trend (or "control") was presented against which deforestation rates can be compared; (2) no counterfactual ${ }^{2}$ (i.e. a scenario in which the hypothesized effects are absent) was formulated to evaluate change in protected area effectiveness; (3) no statistical model was employed to assess the potential relationship between conflict periods and forest loss; and (4) only relative change in rates of forest loss was assessed, which does not account for the fact that the same relative change can lead to markedly different deforestation trajectories, depending on the initial deforestation rates. In our reanalysis of the data, we found that forests in national protected areas are actually less vulnerable than other forests in the face of post-conflict transition. The original study only happens to notice a national trend of increased forest loss that is also present in protected areas, albeit to a much smaller degree. In addition, we find it concerning that none of the variables that the authors present as causal drivers for deforestation in protected areas are actually included in their statistical analysis. In the following, we present the results of our reanalysis and the implications for investigating - and acting on - deforestation in protected areas.

\section{Reanalysis}

We structured our reanalysis into two parts. In the first part, we replicated the original analysis, but also compared the relative change in forest loss (between the periods "before" and "after" the peace agreement) to a reference trend. In the second part, we conducted a more comprehensive statistical analysis to also address the other shortcomings identified above. Following the methods by Clerici et al. ${ }^{1}$, the extent of forest loss in our replication (Supplementary Tables S1, S2) closely matched that reported in the original study (Pearson's $r>0.99$ ). In addition, we calculated a national-level reference trend of forest loss 
observed outside the assessed protected areas and buffer zones. The percentage increase of forest loss within national protected areas (median: $121.7 \%$, range: $790.2 \%$ ) is different from zero (sign test, $k=31, n=39, p<0.01$ ), but it is not significantly different (sign test, $k=19, n=39, p>0.99)$ from the reference trend $(116 \%)$. The percentage increase within 10-kilometre buffer zones around protected areas (median: 158,0\%, range: 698,6\%) also does not differ significantly from the reference trend (sign test, $k=23, n=39, p=0.34$ ). Therefore, forests in national protected areas (and their buffer zones) do not appear to be more heavily affected by post-conflict transition than forests elsewhere in Colombia, contrary to the conclusions of Clerici et al. ${ }^{1}$.

For the second part of our reanalysis, we formulated a generalized linear mixed model (Supplementary methods; Supplementary Tables S3 - S5) to assess the effect of post-conflict transition on forest loss (Fig. 1). To compare deforestation trajectories, we used proportional forest loss, which expresses forest area lost as a percentage of total forest area (see Supplementary methods, Supplementary Tables S1, S2). In addition to the national reference trend, we used a counterfactual stated as: "the proportion of forest area lost within protected areas and buffer zones increases by the same amount as in Colombian forests outside these areas". We consider this the simplest counterfactual in the context of the original study, but other types of counterfactuals can surely be formulated ${ }^{3,4}$.

Two main results arise from the regression analysis. First, protected areas show far less forest loss than other forested areas in Colombia, both "before" and "after" peace negotiations (Fig. 1). This is a key aspect missing from the original analysis: it essentially explains why, for protected areas, a similar relative change over time translates to a deforestation trajectory that is substantially different from both the reference trend and counterfactual (Table 1). As a second result, the difference in proportional forest loss between protected areas and the counterfactual (Table 1) has widened during post-conflict transition which means that the proportion of forest area spared from deforestation has increased compared to the counterfactual and reference trend. In contrast, the trajectory for buffer zones closely tracks the counterfactual (Fig. 1). These results show that protected areas are effective at reducing deforestation compared to forests elsewhere. It can even be argued that their effectiveness has increased relative to other forested areas. Some caution is warranted when interpreting these trends, however, as much of the variation in forest loss remains unexplained by our model (total deviance explained: 19.7\%; Supplementary Tables S4, S5).

In summary, whatever drivers act upon forests in Colombian national protected areas during post-conflict transition, their overall effect leads to these forests being less affected by the transition than other forests. In the original study ${ }^{1}$, the authors repeatedly point to weak institutions and a higher incidence of illicit crops as the drivers that specifically affect protected areas, and argue that these drivers cause protected areas to be particularly prone to deforestation during post-conflict periods. However, their statistical analysis does not actually include the drivers they propose. Taken together, this omission and the results of our reanalysis indicate that the argument in the original study ${ }^{1}$ - i.e. attributing deforestation under post-conflict transition to the purported drivers - is not supported by the available data and therefore remains entirely speculative. The same must thus be said about the conservation implications that were derived from this argument. For example: when extending beyond the Colombian situation, the authors argue in favour of an increased presence of a central government during post-conflict transition. However, their analysis does not provide evidence for why this strategy could be effective, or why it should be preferred over alternative (or complementary) strategies such as strengthening local indigenous or community-level institutions ${ }^{5-7}$.

\section{Implications for forest change research and policy}

Deforestation is the result of multiple interacting drivers ${ }^{8,9}$ (which is also acknowledged by Clerici et al. ${ }^{1}$ ). And like the original study, our reanalysis remains strongly limited in identifying causal drivers, as only one potential driver (the cessation of armed conflict) is included as a predictor variable, without controlling for other (and potentially confounding) variables. In comparing forest loss inside protected areas to the simple counterfactual we defined, we have used a rather coarse measure of protected area effectiveness, and other indicators would be needed to judge performance regarding ecosystem service provision and well-being of the local population ${ }^{10,11}$. In addition to weak conservation institutions and presence of illicit crops (as proposed by Clerici et al. ${ }^{1}$ ), forest loss in protected areas could be influenced by numerous biophysical and social variables, such as distance to roads, terrain ruggedness, soil fertility, population density, and availability of alternative income sources for the local population, to name but a few. For some of these factors, geospatial information is readily available and can be integrated into statistical models. Others, however, may require detailed ground surveys or in-depth interviews ${ }^{12}$. Understandably, the latter are difficult to obtain in situations of armed conflict. Nonetheless, if a certain factor is absent from the analysis, we strongly suggest that its effect on forest loss be treated as a hypothesis rather than a demonstrated cause. For example, while it is entirely possible that institutions related to protected area governance are weak - contributing to increased deforestation relative to non-protected areas - it is also possible that other factors (such as remoteness) produce counteracting effects strong enough to result in overall reduced deforestation, relative to non-protected areas, as we have observed for Colombia. Teasing apart a set of spatially concurrent drivers based on well-defined hypotheses thus remains important ${ }^{13}$ for arriving at effective "lessons" for conservation. 
Combining forest change data (such as provided by Hansen et al. ${ }^{14}$ ) with other geospatial information can provide important insights into deforestation patterns. To fully leverage these data while accounting for different drivers of forest loss, we suggest that studies follow a more rigorous statistical approach and, whenever possible, use statistical models to quantify relationships between deforestation and its potential drivers. While a comprehensive discussion of these methods is beyond the scope of this comment, we suggest that at least the following aspects be taken into account. First, to fully take advantage of high-resolution forest loss data (e.g. at 1 arc-second), we suggest using observations at the level of single raster cells. The observed response will then be a binary variable ("no forest loss" or "forest loss") for a given location (i.e. raster cell) in a given year (or otherwise defined time period). Alternatively, patches of several raster cells may be aggregated (e.g. patches of $3 \times 3$ cells) and forest loss events counted per patch, with the response now being a count variable. Both methods avoid having to spatially aggregate forest loss for areas that differ widely in size (which is often the case for protected areas). In addition, data on forest loss is then structured similar to species presence-absence data (or abundance data in the aggregated case), taking advantage of the rich toolbox that has been developed for analyzing them ${ }^{15-17}$. Conceptualizing forest loss in this way also provides vastly more observations, which means (in principle) that more potential drivers of forest loss can be included as predictors in statistical models. Second, the selection of variables that may be linked to deforestation should be informed both by $a$ priori hypotheses, and by a systematic literature review for the location of interest, in order to identify potential confounding variables. Finally, as drivers of forest loss may not be independent, any collinearity between predictors should be accounted for ${ }^{18}$, and its effects should be discussed when causal interpretation of the predictor variables is attempted. In the context of Colombian forests, a good example for a more rigorous statistical approach is given by a recent study demonstrating a link between deforestation and forest fires ${ }^{19}$; whereas another recent study on drivers of deforestation ${ }^{20}$ does not take the aforementioned aspects into account and is affected by most of the shortcomings discussed above.

With this comment we would like to encourage researchers to use readily available geospatial information on deforestation and its potential drivers to investigate policy-relevant questions, such as Clerici et al. ${ }^{1}$ have done. We greatly appreciate that the authors have brought this concerning trend of increased deforestation in Colombia to our attention, and we believe that more studies on underlying causes of deforestation are needed to improve forest governance. For future studies on forest change to be most relevant for policymaking, however, they should aim to provide the strongest supporting evidence achievable - given the available data and the question at hand. This requires that analytical concepts and statistical methods be as robust as possible, and interdependencies and uncertainties related to potential drivers of forest loss be clearly communicated.

\section{Data availability}

The analysis scripts used in this study are available as a git repository (https://www.github.com/dschoenig/ ForestchangeColPA) and have been archived under DOI 10.5281/zenodo.3984087.

\section{References}

1. Clerici, N. et al. Deforestation in Colombian protected areas increased during post-conflict periods. Sci. Reports 10, 1-10, DOI: 10.1038/s41598-020-61861-y (2020).

2. Ferraro, P. J. \& Hanauer, M. M. Advances in Measuring the Environmental and Social Impacts of Environmental Programs. Annu. Rev. Environ. Resour. 39, 495-517, DOI: 10.1146/annurev-environ-101813-013230 (2014).

3. Maron, M. et al. The many meanings of no net loss in environmental policy. Nat. Sustain. 1, 19-27, DOI: 10.1038/ s41893-017-0007-7 (2018).

4. Bull, J. W., Strange, N., Smith, R. J. \& Gordon, A. Reconciling multiple counterfactuals when evaluating biodiversity conservation impact in social-ecological systems. Conserv. Biol. cobi.13570, DOI: 10.1111/cobi.13570 (2020).

5. Bonilla-Mejía, L. \& Higuera-Mendieta, I. Protected Areas under Weak Institutions: Evidence from Colombia. World Dev. 122, 585-596, DOI: 10.1016/j.worlddev.2019.06.019 (2019).

6. Mateo-Vega, J. et al. Full and effective participation of indigenous peoples in forest monitoring for reducing emissions from deforestation and forest degradation (REDD+): Trial in Panama's Darién. Ecosphere 8, e01635, DOI: 10.1002/ecs2.1635 (2017).

7. Nagendra, H. \& Ostrom, E. Polycentric governance of multifunctional forested landscapes. Int. J. Commons 6, 104-133, DOI: 10.18352/ijc.321 (2012).

8. Curtis, P. G., Slay, C. M., Harris, N. L., Tyukavina, A. \& Hansen, M. C. Classifying drivers of global forest loss. Science 361, 1108-1111, DOI: 10.1126/science.aau3445 (2018). 
9. Armenteras, D., Espelta, J. M., Rodríguez, N. \& Retana, J. Deforestation dynamics and drivers in different forest types in Latin America: Three decades of studies (1980-2010). Glob. Environ. Chang. 46, 139-147, DOI: 10.1016/j.gloenvcha. 2017.09.002 (2017).

10. Watson, J. E. M., Dudley, N., Segan, D. B. \& Hockings, M. The performance and potential of protected areas. Nature 515, 67-73, DOI: 10.1038/nature13947 (2014).

11. Nagendra, H., Reyers, B. \& Lavorel, S. Impacts of land change on biodiversity: Making the link to ecosystem services. Curr. Opin. Environ. Sustain. 5, 503-508, DOI: 10.1016/j.cosust.2013.05.010 (2013).

12. Hoffmann, C., García Márquez, J. R. \& Krueger, T. A local perspective on drivers and measures to slow deforestation in the Andean-Amazonian foothills of Colombia. Land Use Policy 77, 379-391, DOI: 10.1016/j.landusepol.2018.04.043 (2018).

13. Spake, R. et al. An analytical framework for spatially targeted management of natural capital. Nat. Sustain. 2, 90-97, DOI: 10.1038/s41893-019-0223-4 (2019).

14. Hansen, M. C. et al. High-resolution global maps of 21st-century forest cover change. Science 342, 850-853, DOI: 10.1126/science.1244693 (2013).

15. Isaac, N. J. B. et al. Data Integration for Large-Scale Models of Species Distributions. Trends Ecol. \& Evol. 35, 56-67, DOI: 10.1016/j.tree.2019.08.006 (2020).

16. Guillera-Arroita, G. et al. Is my species distribution model fit for purpose? Matching data and models to applications. Glob. Ecol. Biogeogr. 24, 276-292, DOI: 10.1111/geb.12268 (2015).

17. Elith, J. \& Leathwick, J. R. Species Distribution Models: Ecological Explanation and Prediction Across Space and Time. Annu. Rev. Ecol. Evol. Syst. 40, 677-697, DOI: 10.1146/annurev.ecolsys.110308.120159 (2009).

18. Dormann, C. F. et al. Collinearity: A review of methods to deal with it and a simulation study evaluating their performance. Ecography 36, 27-46, DOI: 10.1111/j.1600-0587.2012.07348.x (2013).

19. Armenteras, D., Schneider, L. \& Dávalos, L. M. Fires in protected areas reveal unforeseen costs of Colombian peace. Nat. Ecol. \& Evol. 3, 20-23, DOI: 10.1038/s41559-018-0727-8 (2019).

20. Anaya, J. A. et al. Drivers of Forest Loss in a Megadiverse Hotspot on the Pacific Coast of Colombia. Remote. Sens. 12, 1235, DOI: 10.3390/rs12081235 (2020).

\section{Ackowledgements}

The work of DS is supported by the Natural Sciences and Engineering Research Council of Canada (NSERC) as part of the CREATE programme Biodiversity Ecosystem Services and Sustainability (BESS).

\section{Author contributions statement}

DS replicated the original study, performed additional statistical analyses, and lead writing of the manuscript. CM and JD contributed to discussing and writing the manuscript.

\section{Additional information}

\section{Competing interests}

The authors declare no competing interests. 


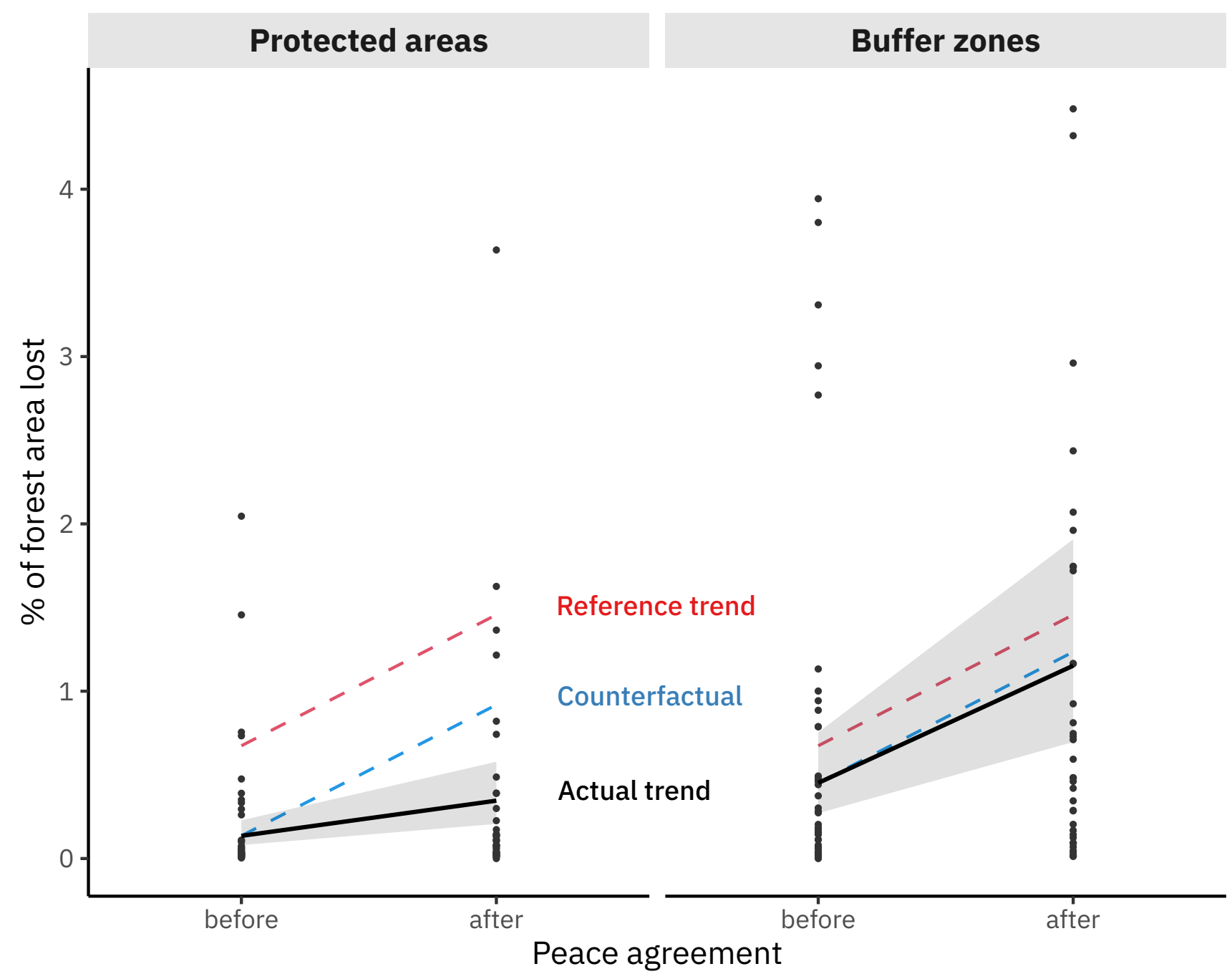

Figure 1. Comparison of forest loss before and after the peace agreement. While post-conflict transition coincides with a general increase in deforestation at the national level, national protected areas suffered only a relatively small increase in forest loss. The black line shows the predictions of a generalized linear mixed model (Supplementary Information) fitted on these observations. 95\% confidence intervals are shown in grey. The red dashed lined corresponds to the percentage of forest area lost for Colombian forested land lying outside the assessed protected areas and buffer zones. The blue dashed line represents a hypothetical scenario in which forest loss increases at the same rate as outside protected areas and their buffer zones, but starting at the level of the actually observed forest loss before the peace agreement. Individual observations for national protected areas and their 10-kilometre buffer zones, respectively, are shown as black points. Observations for one protected area and three buffer zones in the period after the peace agreement are not shown due to high rates of forest loss $(>7.3 \%$ of forest area lost), but they have been included in the regression model. 
Table 1. Model predictions compared to reference trend and counterfactual.

\begin{tabular}{|c|c|c|c|}
\hline \multirow{2}{*}{ Period $^{\mathrm{a}}$} & \multirow{2}{*}{$\begin{array}{c}\text { Forest loss } \\
(\% \text { of total forested area })^{b}\end{array}$} & \multicolumn{2}{|c|}{ Difference in forest loss $v s .^{\mathrm{c}}$} \\
\hline & & Reference trend $^{\mathrm{d}}$ & Counterfactual $^{\mathrm{e}}$ \\
\hline \multicolumn{4}{|c|}{ Protected a } \\
\hline before & $0.136(0.080$, & $-0.584(-0.639,-0$. & $0(-0.055,0.093)$ \\
\hline after & $0.346(0.207,0.579)$ & $-1.208(-1.347,-0.975)$ & $-0.624(-0.763,-0.391)$ \\
\hline \multicolumn{4}{|c|}{ Buffer zones } \\
\hline before & $0.452(0.271,0.754)$ & $-0.268(-0.449,0$ & $0(-0.181,0.302)$ \\
\hline after & $1.153(0.696,1.908)$ & $-0.401(-0.858$ & $-0.133(-0.590,0.622)$ \\
\hline \multicolumn{4}{|c|}{$\begin{array}{l}\text { a Refers to the three-year periods before }(2013-2015) \text { or after }(2016-2018) \text { the peace agreement was negotiated. } \\
\text { b Total forested area was defined as the combined area of all raster cells with at least } 50 \% \text { tree cover in the year } 2000 \text {, and } \\
\text { with no forest loss recorded prior to } 2013.95 \% \text { confidence intervals are given in parentheses. } \\
\text { c Absolute difference. Negative values indicate that estimated proportional forest loss is lower than the reference trend or the } \\
\text { counterfactual, respectively. } 95 \% \text { confidence intervals are given in parentheses. } \\
\text { d Defined as the percentage of forest area lost outside the assessed protected areas and buffer zones in Colombia. } \\
\text { e Hypothetical scenario defined as: "the proportion of forest area lost within protected areas and buffer zones, respectively, } \\
\text { increases by the same amount as in Colombian forests outside these areas". }\end{array}$} \\
\hline
\end{tabular}




\section{SUPPLEMENTARY INFORMATION}

\section{Comment: The effect of post-conflict transition on deforestation in protected areas in Colombia}

Daniel Schoenig ${ }^{1,{ }^{*}}$, Jérôme Dupras ${ }^{2}$, and Christian Messier ${ }^{1,2}$

${ }^{1}$ Département des Sciences Biologiques, Université du Québec à Montréal, Montréal, QC, Canada

${ }^{2}$ Département des Sciences Naturelles, Institut des Sciences de la Forêt Tempérée, Université du Québec en Outaouais, Ripon, QC, Canada

*daniel.schoenig@protonmail.com

\section{Contents}

1 Supplementary methods

2 Supplementary tables

References 


\section{Supplementary methods}

We generally followed the methods of the original study (as documented in the main text and the supplementary information) and used the data sources documented therein. The analysis scripts and final results have been archived under DOI 10.5281/zenodo.3984087.

\section{Geospatial analysis}

The global forest change data sets (referenced in the main text) provide, for each raster cell, tree cover estimates in percent for the year 2000. In the original study, the authors do not report whether they used a tree cover threshold to exclude barely forested land from their analysis. We therefore decided to chose a threshold ourselves and included only raster cells with at least 50\% tree cover. For absolute forest loss in the periods before and after the peace agreement, we assessed agreement between our replication and the original study by calculating correlation coefficients (Pearson's $r$ ).

In addition to forest loss, we also calculated the total forested area for each protected area and buffer zone. We defined total forested area as the combined extent of all raster cells with at least 50\% tree cover in the year 2000, and with no forest loss recorded prior to 2013. This is a conservative estimate of total forested area as it does not include newly planted or regenerating forests in areas that were below the tree cover threshold in the year 2000. To calculate forest loss and total forest area for Colombia, we applied the same methods we used for protected areas and buffer zones. Forest loss outside protected areas and buffer zones was then obtained by subtracting forest loss calculated for protected areas and buffer zones from the national total. We took this as the reference trend (or "control") against which to compare deforestation rates in individual protected areas and their buffer zones.

The relative change (expressed in percent) between the three-year periods before (2013 - 2015) and after $(2016$ - 2018) the peace agreement are calculated in the same way as in the original study:

$$
100 \times \frac{\text { forest loss before }- \text { forest loss after }}{\text { forest loss before }}
$$

For each region of interest (i.e. protected areas, their buffer zones, and Colombia as a whole), we also expressed forest loss as a percentage of total forested area (as defined above) in the respective region, calculating for each period separately:

$$
100 \times \frac{\text { forest loss over period }}{\text { total forested area }}
$$

Proportional forest loss allows to better compare deforestation between different areas, because it includes differences in initial deforestation rates. This is important because areas that experience the same relative change in deforestation can move along strongly diverging trajectories according to the initial amount of forest loss.

\section{Replication of original analysis}

In our replication of the original study, we tested whether the observed relative change of deforestation is different from zero, separately for protected areas, and their buffer zones. In addition, we also tested whether the observed change was different from the relative change observed for Colombian forests outside the assessed protected areas and buffer zones. Given that the relative changes in forest loss are distributed asymmetrically around the median, we consider the Wilcoxon signed-rank test - as used in the original study - an inadequate choice, and instead used the more general sign-test.

\section{Extended statistical analysis}

We analyzed deforestation trajectories by formulating regression models on the percent of forest area lost as the response variable. Given that each buffer zone pertains to a specific protected area (i.e. buffer zones and protected areas are not independent). We therefore included both types of areas in our models, and formulated two grouping variables: the type of area ("buffer zone" or "protected area") and the protected area ID to indicate which protected area and buffer zone are paired. We formulated four models differing in the linear combination of their predictor variables (Supplementary Table S3): (1) an intercept-only model; (2) a model based on conflict period ("before" or "after") and type; (3) same as the second model but including a random intercept based on protected area ID; (4) same as the third model but also containing an interaction term between conflict period and type. Inspection of the data suggested that an adequate distribution for the percentage of forest area lost would have to be heavy-tailed (towards the upper end) and be able to accommodate a concrete probability mass at zero. We therefore chose the Tweedie distribution, with scale parameter $\phi$ and power parameter $p$ to be estimated as part of the fitting process. As link function we used the natural logarithm. We used Akaike's information criterion (corrected for small sample size) to select the final model out of the four candidate models, and did not perform further variable selection. For fixed effects, $p$-values were computed based on Wald tests in which the Bayesian covariance matrix was used ${ }^{21}$; for the random intercept term, $p$-values are based on a likelihood ratio statistic ${ }^{22}$. 


\section{Software}

For data handling and geospatial analyses we used the GDAL ${ }^{23}$ command line utilities and the following packages for $R^{24}$ (version 4.0.2): gdalUtils ${ }^{25}$, stars $^{26}, s f^{27}$, lwgeom $^{28}$, units ${ }^{29}$ and the tidyverse $e^{30}$ packages. For statistical analyses we used the $m g c v^{31}$ and $M u M I N^{32} \mathrm{R}$ packages. 


\section{Supplementary tables}

Table S1. Forest loss in Colombian national protected areas and national nature reserves.

\begin{tabular}{|c|c|c|c|c|c|c|}
\hline \multirow[t]{2}{*}{ ID } & \multirow[t]{2}{*}{ Name } & \multirow[t]{2}{*}{$\begin{array}{l}\text { Initial forest area } \\
\qquad\left(\mathrm{km}^{2}\right)\end{array}$} & \multicolumn{2}{|c|}{$\begin{array}{l}\text { Absolute forest loss } \\
\qquad\left(\mathrm{km}^{2}\right)\end{array}$} & \multicolumn{2}{|c|}{$\begin{array}{l}\text { Proportional forest loss } \\
\text { (\% of initial forest area) }\end{array}$} \\
\hline & & & before $^{b}$ & $\operatorname{after}^{c}$ & before ${ }^{b}$ & $\operatorname{after}^{c}$ \\
\hline 1 & $\begin{array}{l}\text { Alto Fragua - Indi } \\
\text { Wasi }\end{array}$ & 752.972 & 0.365 & 0.586 & 0.048 & 0.078 \\
\hline 2 & Amacayacu & $2,619.180$ & 0.799 & 1.718 & 0.031 & 0.066 \\
\hline 3 & Cahuinarí & $5,487.014$ & 0.386 & 1.401 & 0.007 & 0.026 \\
\hline 4 & Catatumbo Barí & $1,561.293$ & 11.793 & 56.783 & 0.755 & 3.637 \\
\hline 5 & Chingaza & 466.523 & 0.078 & 0.618 & 0.017 & 0.133 \\
\hline 6 & $\begin{array}{l}\text { Complejo } \\
\text { Volcánico Doña } \\
\text { Juana Cascabel }\end{array}$ & 619.749 & 0.083 & 0.248 & 0.013 & 0.040 \\
\hline 7 & $\begin{array}{l}\text { Cordillera de los } \\
\text { Picachos }\end{array}$ & $2,754.313$ & 10.745 & 33.486 & 0.390 & 1.216 \\
\hline 8 & $\begin{array}{l}\text { Cueva de los } \\
\text { Guácharos }\end{array}$ & 70.699 & 0.004 & 0 & 0.005 & 0 \\
\hline 9 & El Cocuy & $1,621.238$ & 0.348 & 2.221 & 0.021 & 0.137 \\
\hline 10 & El Tuparro & 937.267 & 0.647 & 2.804 & 0.069 & 0.299 \\
\hline 11 & La Paya & $4,327.761$ & 20.574 & 32.127 & 0.475 & 0.742 \\
\hline 12 & Las Hermosas & 680.614 & 0.260 & 0.522 & 0.038 & 0.077 \\
\hline 13 & Las Orquídeas & 280.539 & 0.212 & 1.092 & 0.076 & 0.389 \\
\hline 14 & $\begin{array}{l}\text { Los Farallones de } \\
\text { Cali }\end{array}$ & $1,898.444$ & 0.550 & 1.470 & 0.029 & 0.077 \\
\hline 15 & Los Katíos & 662.541 & 0.365 & 1.144 & 0.055 & 0.173 \\
\hline 16 & Los Nevados & 101.206 & 0.020 & 0.010 & 0.020 & 0.010 \\
\hline 17 & Macuira & 52.215 & 0.154 & 0.030 & 0.295 & 0.058 \\
\hline 18 & Munchique & 457.022 & 1.193 & 2.226 & 0.261 & 0.487 \\
\hline 19 & Nevado del Huila & $1,220.238$ & 0.350 & 0.240 & 0.029 & 0.020 \\
\hline 20 & Nukak & $8,615.641$ & 9.384 & 19.499 & 0.109 & 0.226 \\
\hline 21 & Paramillo & $4,889.628$ & 17.180 & 40.128 & 0.351 & 0.821 \\
\hline 22 & Pisba & 177.134 & 0.046 & 0.258 & 0.026 & 0.146 \\
\hline 23 & Puinawai & $10,833.330$ & 6.358 & 11.814 & 0.059 & 0.109 \\
\hline 24 & Puracé & 728.412 & 0.120 & 0.295 & 0.016 & 0.041 \\
\hline 25 & Río Puré & $9,856.320$ & 0.380 & 1.564 & 0.004 & 0.016 \\
\hline 26 & Sanquianga & 484.177 & 0.532 & 0.678 & 0.110 & 0.140 \\
\hline 27 & Selva de Florencia & 98.894 & 0.031 & 0.031 & 0.032 & 0.031 \\
\hline 28 & $\begin{array}{l}\text { Serranía de } \\
\text { Chiribiquete }\end{array}$ & $27,217.876$ & 3.590 & 3.765 & 0.013 & 0.014 \\
\hline 29 & $\begin{array}{l}\text { Serranía de los } \\
\text { Churumbelos - } \\
\text { Auka Wasi }\end{array}$ & 967.892 & 0.427 & 0.357 & 0.044 & 0.037 \\
\hline
\end{tabular}


Table S1. (continued)

\begin{tabular}{|c|c|c|c|c|c|c|}
\hline \multirow[t]{2}{*}{ ID } & \multirow[t]{2}{*}{ Name } & \multirow[t]{2}{*}{$\begin{array}{l}\text { Initial forest area } \\
\qquad\left(\mathrm{km}^{2}\right)\end{array}$} & \multicolumn{2}{|c|}{$\begin{array}{l}\text { Absolute forest loss } \\
\qquad\left(\mathrm{km}^{2}\right)\end{array}$} & \multicolumn{2}{|c|}{$\begin{array}{l}\text { Proportional forest loss } \\
\text { (\% of initial forest area) }\end{array}$} \\
\hline & & & before $^{b}$ & $\operatorname{after}^{\mathrm{c}}$ & before ${ }^{b}$ & after $^{c}$ \\
\hline 30 & $\begin{array}{l}\text { Serranía de los } \\
\text { Yariguies }\end{array}$ & 589.256 & 0.216 & 0.615 & 0.037 & 0.104 \\
\hline 31 & $\begin{array}{l}\text { Sierra de la } \\
\text { Macarena }\end{array}$ & $5,748.020$ & 42.160 & 93.483 & 0.733 & 1.626 \\
\hline 32 & $\begin{array}{l}\text { Sierra Nevada de } \\
\text { Santa Marta }\end{array}$ & $2,342.431$ & 7.809 & 31.975 & 0.333 & 1.365 \\
\hline 33 & Sumapaz & 985.404 & 0.172 & 0.309 & 0.017 & 0.031 \\
\hline 34 & Tamá & 426.736 & 0.423 & 1.670 & 0.099 & 0.391 \\
\hline 35 & Tatamá & 420.414 & 0.123 & 0.104 & 0.029 & 0.025 \\
\hline 36 & Tayrona & 114.337 & 1.665 & 0.019 & 1.456 & 0.017 \\
\hline 37 & Tinigua & $1,855.491$ & 37.963 & 161.290 & 2.046 & 8.693 \\
\hline 38 & Utría & 513.499 & 0.147 & 0.582 & 0.029 & 0.113 \\
\hline 39 & Yaigojé Apaporis & $10,321.017$ & 6.633 & 8.283 & 0.064 & 0.080 \\
\hline
\end{tabular}

${ }^{a}$ Defined as the combined area of all raster cells with at least 50\% tree cover in the year 2000, and with no forest loss recorded prior to 2013 (see Supplementary methods).

b The three-year period $2013-2015$.

c The three-year period $2016-2018$.

Table S2. Forest loss in 10-kilometre buffer zones of Colombian national protected areas and national nature reserves.

\begin{tabular}{|c|c|c|c|c|c|c|}
\hline \multirow[t]{2}{*}{ ID } & \multirow[t]{2}{*}{$\begin{array}{l}\text { Corresponding } \\
\text { protected area }\end{array}$} & \multirow[t]{2}{*}{$\begin{array}{l}\text { Initial forest area } \\
\qquad\left(\mathrm{km}^{2}\right)\end{array}$} & \multicolumn{2}{|c|}{$\begin{array}{l}\text { Absolute forest loss } \\
\qquad\left(\mathrm{km}^{2}\right)\end{array}$} & \multicolumn{2}{|c|}{$\begin{array}{l}\text { Proportional forest loss } \\
\text { (\% of initial forest area) }\end{array}$} \\
\hline & & & before $^{b}$ & $\operatorname{after}^{c}$ & before $^{b}$ & $\operatorname{after}^{\mathrm{c}}$ \\
\hline 1 & $\begin{array}{l}\text { Alto Fragua - Indi } \\
\text { Wasi }\end{array}$ & 832.894 & 8.337 & 14.325 & 1.001 & 1.720 \\
\hline 2 & Amacayacu & $2,577.405$ & 3.714 & 3.217 & 0.144 & 0.125 \\
\hline 3 & Cahuinarí & $3,664.800$ & 0.748 & 1.211 & 0.020 & 0.033 \\
\hline 4 & Catatumbo Barí & $1,453.194$ & 42.793 & 108.271 & 2.945 & 7.451 \\
\hline 5 & Chingaza & $1,276.829$ & 0.538 & 1.202 & 0.042 & 0.094 \\
\hline 6 & $\begin{array}{l}\text { Complejo } \\
\text { Volcánico Doña } \\
\text { Juana Cascabel }\end{array}$ & $1,281.750$ & 1.893 & 3.651 & 0.148 & 0.285 \\
\hline 7 & $\begin{array}{l}\text { Cordillera de los } \\
\text { Picachos }\end{array}$ & $1,930.671$ & 9.523 & 57.173 & 0.493 & 2.961 \\
\hline 8 & $\begin{array}{l}\text { Cueva de los } \\
\text { Guácharos }\end{array}$ & 127.389 & 0.598 & 2.220 & 0.469 & 1.743 \\
\hline 9 & El Cocuy & $2,075.424$ & 1.668 & 7.155 & 0.080 & 0.345 \\
\hline 10 & El Tuparro & 769.214 & 3.395 & 7.113 & 0.441 & 0.925 \\
\hline 11 & La Paya & $2,587.724$ & 71.681 & 115.940 & 2.770 & 4.480 \\
\hline 12 & Las Hermosas & $1,614.442$ & 2.509 & 7.804 & 0.155 & 0.483 \\
\hline 13 & Las Orquídeas & $1,162.301$ & 1.994 & 9.431 & 0.172 & 0.811 \\
\hline
\end{tabular}

(continued on next page) 
Table S2. (continued)

\begin{tabular}{|c|c|c|c|c|c|c|}
\hline \multirow[t]{2}{*}{ ID } & \multirow[t]{2}{*}{$\begin{array}{l}\text { Corresponding } \\
\text { protected area }\end{array}$} & \multirow[t]{2}{*}{$\begin{array}{l}\text { Initial forest area }{ }^{\mathrm{a}} \\
\qquad\left(\mathrm{km}^{2}\right)\end{array}$} & \multicolumn{2}{|c|}{$\begin{array}{l}\text { Absolute forest loss } \\
\qquad\left(\mathrm{km}^{2}\right)\end{array}$} & \multicolumn{2}{|c|}{$\begin{array}{l}\text { Proportional forest loss } \\
\text { (\% of initial forest area) }\end{array}$} \\
\hline & & & before $^{b}$ & $\operatorname{after}^{\mathrm{c}}$ & before $^{b}$ & after $^{c}$ \\
\hline 14 & $\begin{array}{l}\text { Los Farallones de } \\
\text { Cali }\end{array}$ & $1,977.895$ & 3.671 & 5.693 & 0.186 & 0.288 \\
\hline 15 & Los Katíos & 899.553 & 7.970 & 38.860 & 0.886 & 4.320 \\
\hline 16 & Los Nevados & $1,141.070$ & 4.275 & 5.505 & 0.375 & 0.482 \\
\hline 17 & Macuira & 1.598 & 0 & 0.001 & 0 & 0.047 \\
\hline 18 & Munchique & $1,301.171$ & 10.247 & 25.521 & 0.788 & 1.961 \\
\hline 19 & Nevado del Huila & $2,541.519$ & 7.173 & 18.990 & 0.282 & 0.747 \\
\hline 20 & Nukak & $5,433.456$ & 8.462 & 39.661 & 0.156 & 0.730 \\
\hline 21 & Paramillo & $3,767.065$ & 29.706 & 91.779 & 0.789 & 2.436 \\
\hline 22 & Pisba & 803.174 & 0.475 & 3.373 & 0.059 & 0.420 \\
\hline 23 & Puinawai & $5,013.538$ & 1.836 & 3.494 & 0.037 & 0.070 \\
\hline 24 & Puracé & $1,686.545$ & 0.597 & 1.545 & 0.035 & 0.092 \\
\hline 25 & Río Puré & $3,686.698$ & 0.288 & 0.631 & 0.008 & 0.017 \\
\hline 26 & Sanquianga & 799.613 & 3.870 & 4.746 & 0.484 & 0.594 \\
\hline 27 & Selva de Florencia & 614.650 & 2.833 & 10.735 & 0.461 & 1.746 \\
\hline 28 & $\begin{array}{l}\text { Serranía de } \\
\text { Chiribiquete }\end{array}$ & $10,187.658$ & 2.458 & 1.291 & 0.024 & 0.013 \\
\hline 29 & $\begin{array}{l}\text { Serranía de los } \\
\text { Churumbelos - } \\
\text { Auka Wasi }\end{array}$ & $1,320.814$ & 12.456 & 23.052 & 0.943 & 1.745 \\
\hline 30 & $\begin{array}{l}\text { Serranía de los } \\
\text { Yariguies }\end{array}$ & $1,461.122$ & 2.979 & 17.000 & 0.204 & 1.163 \\
\hline 31 & $\begin{array}{l}\text { Sierra de la } \\
\text { Macarena }\end{array}$ & $3,238.298$ & 107.147 & 295.494 & 3.309 & 9.125 \\
\hline 32 & $\begin{array}{l}\text { Sierra Nevada de } \\
\text { Santa Marta }\end{array}$ & $2,675.664$ & 30.311 & 55.384 & 1.133 & 2.070 \\
\hline 33 & Sumapaz & $2,092.728$ & 1.401 & 4.276 & 0.067 & 0.204 \\
\hline 34 & Tamá & 734.966 & 2.008 & 5.221 & 0.273 & 0.710 \\
\hline 35 & Tatamá & $1,314.390$ & 3.972 & 15.330 & 0.302 & 1.166 \\
\hline 36 & Tayrona & 245.020 & 9.314 & 1.130 & 3.801 & 0.461 \\
\hline 37 & Tinigua & 788.178 & 31.080 & 104.846 & 3.943 & 13.302 \\
\hline 38 & Utría & 909.286 & 1.017 & 1.530 & 0.112 & 0.168 \\
\hline 39 & Yaigojé Apaporis & $5,875.261$ & 6.694 & 8.399 & 0.114 & 0.143 \\
\hline
\end{tabular}

${ }^{a}$ Defined as the combined area of all raster cells with at least $50 \%$ tree cover in the year 2000, and with no forest loss recorded prior to 2013 (see Supplementary methods).

b The three-year period $2013-2015$.

c The three-year period 2016-2018. 
Table S3. Regression models considered.

\begin{tabular}{|c|c|c|c|c|c|c|}
\hline \multirow{2}{*}{ Model $^{\mathrm{a}}$} & \multicolumn{4}{|c|}{ Effects } & \multirow{2}{*}{ Distribution } & \multirow{2}{*}{ Link } \\
\hline & $\begin{array}{l}\text { Conflict } \\
\text { period }^{b}\end{array}$ & Type $^{c}$ & $\begin{array}{l}\text { Conflict period } \times \\
\text { type }^{d}\end{array}$ & $\begin{array}{l}\text { Protected area ID } \mathrm{e} \\
\text { (random intercept) }\end{array}$ & & \\
\hline 1 & & & & & Tweedie & $\log$ \\
\hline 2 & $\mathrm{X}$ & $X$ & & & Tweedie & $\log$ \\
\hline 3 & $X$ & $X$ & & $\mathrm{X}$ & Tweedie & $\log$ \\
\hline 4 & $X$ & $X$ & $\mathrm{X}$ & $\mathrm{X}$ & Tweedie & $\log$ \\
\hline
\end{tabular}

Table S4. Model selection.

\begin{tabular}{llrrrr}
\hline Model & Distribution parameters $^{\mathrm{a}}$ & $\mathrm{DF}^{\mathrm{b}}$ & Dev. expl. $^{\mathrm{c}}$ & $\mathrm{R}^{2}$ (adj.) & $\mathrm{AIC}_{c}{ }^{\mathrm{d}}$ \\
\hline 1 & Tweedie $(\phi=2.211, p=1.920)$ & 3 & $<0.1 \%$ & 0 & 199.3 \\
2 & Tweedie $(\phi=1.851, p=1.906)$ & 5 & $16.9 \%$ & 0.087 & 163.5 \\
$\mathbf{3}$ (selected) & Tweedie $(\phi=1.795, p=1.904)$ & 5.97 & $19.7 \%$ & 0.100 & $\mathbf{1 5 8 . 2}$ \\
4 & Tweedie $(\phi=1.803, p=1.905)$ & 6.97 & $19.8 \%$ & 0.095 & 160.3 \\
\hline
\end{tabular}

${ }^{a}$ The scale parameter $\phi$ and Tweedie power parameter $p$ were estimated as part of the fitting process.

${ }^{b}$ Model degrees of freedom.

${ }^{c}$ Deviance explained.

d Akaike information criterion corrected for small sample size.

Table S5. Parameter estimates of the final model.

\begin{tabular}{|c|c|c|c|c|c|}
\hline \multirow{2}{*}{ Parameter } & \multicolumn{3}{|c|}{ Fixed effect } & \multicolumn{2}{|c|}{ Random effect } \\
\hline & Coef. & $\mathrm{SE}^{\mathrm{a}}$ & $95 \% \mathrm{CI}^{\mathrm{b}}$ & $\mathrm{SD}^{\mathrm{c}}$ & $95 \% \mathrm{CI}^{\mathrm{b}}$ \\
\hline Intercept & $-1.998^{* * *}$ & 0.267 & $-2.521,-1.476$ & & \\
\hline After conflict & $0.936^{* * *}$ & 0.220 & $0.505,1.368$ & & \\
\hline Buffer zone & $1.204^{* * *}$ & 0.220 & $0.772,1.635$ & & \\
\hline Protected area ID & & & & $0.021^{*}$ & $0.004,0.106$ \\
\hline
\end{tabular}

Significance levels: ${ }^{*} \mathrm{p}<0.05 ;{ }^{* *} \mathrm{p}<0.01 ;{ }^{* * *} \mathrm{p}<0.001$

a Standard error of the coefficient estimate.

b Point-wise confidence intervals for the regression coefficient (for fixed effects) or standard deviation (for random effects).

c Standard deviation. 


\section{References}

21. Wood, S. N. On p-values for smooth components of an extended generalized additive model. Biometrika 100, 221-228, DOI: 10.1093/biomet/ass048 (2013).

22. Wood, S. N. A simple test for random effects in regression models. Biometrika 100, 1005-1010, DOI: 10.1093/biomet/ ast038 (2013).

23. GDAL/OGR contributors. GDAL/OGR geospatial data abstraction software library (2020).

24. R Core Team. R: A Language and Environment for Statistical Computing. R Foundation for Statistical Computing, Vienna, Austria (2020).

25. Greenberg, J. A. \& Mattiuzzi, M. gdalUtils: Wrappers for the Geospatial Data Abstraction Library (GDAL) Utilities (2020).

26. Pebesma, E. Stars: Spatiotemporal Arrays, Raster and Vector Data Cubes (2020).

27. Pebesma, E. Simple features for $\mathrm{r}$ : Standardized support for spatial vector data. The $R$ J. 10, 439-446, DOI: 10.32614/ RJ-2018-009 (2018).

28. Pebesma, E. Lwgeom: Bindings to Selected 'liblwgeom' Functions for Simple Features (2020).

29. Pebesma, E., Mailund, T. \& Hiebert, J. Measurement units in R. R J. 8, 486-494, DOI: 10.32614/RJ-2016-061 (2016).

30. Wickham, H. et al. Welcome to the tidyverse. J. Open Source Softw. 4, 1686, DOI: 10.21105/joss.01686 (2019).

31. Wood, S. N. Generalized Additive Models: An Introduction with R. Texts in Statistical Science (CRC Press/Taylor \& Francis Group, Boca Raton London New York, 2017), second edition edn.

32. Bartoń, K. MuMIn: Multi-Model Inference (2020). 